\title{
Features of sea-land-breeze circulation over the Seoul Metropolitan Area
}

\author{
Moon-Soo Park * (1) and Jung-Hoon Chae
}

\begin{abstract}
Local circulation plays an important role in producing high-resolution meteorological and air quality information. In this study, detailed surface meteorological and vertical profile features about sea and land breezes in the Seoul Metropolitan Area (SMA) were investigated using the data from urban meteorological observation system in SMA (UMSSeoul). These data were obtained from high-resolution surface meteorological stations and three wind lidar stations for 6 consecutive days (17-22 May 2016) with very weak synoptic winds and low cloud covers. The 6-day average diurnal variations of surface meteorological variables revealed temperature differences between land and sea, driving the pressure differences between the two. This induced sea-land-breeze circulation. The resulting sea breeze began at the shoreline at 1200 local standard time (LST), moved landward at a rate of about $10 \mathrm{~km} \mathrm{~h}^{-1}$, and reached $60 \mathrm{~km}$ from the shoreline at $1800 \mathrm{LST}$. The land breeze occurred within $50 \mathrm{~km}$ of the shoreline until noon. The sea-breeze front was identified by a steep horizontal temperature gradient, and its passage was accompanied by an abrupt temperature drop as well as vapor pressure and wind increases. The time-height cross section of wind indicated that the top of sea (land) breeze reached a maximum height of $1.5 \mathrm{~km}(0.8 \mathrm{~km})$ with maximum winds $0.4 \mathrm{~km}(0.3-0.4 \mathrm{~km})$ high in the late afternoon (early morning). The returning (easterly) flow at 1.5-1.6 km was clearly observed over the sea-breeze cells.
\end{abstract}

Keywords: Local circulation, Pulsed Doppler wind lidar, Sea-land breeze, Sea-breeze front, UMS-Seoul

\section{Introduction}

Local circulations (e.g., sea-land breezes, mountainvalley breezes, and urban-rural breezes) are driven by thermal differences between two different land covers (Simpson 1987). They play an important role on the local weather and air quality in a number of ways. For instance, the nighttime drainage wind, accompanied by a mountain breeze, has been observed over mountainous regions, often causing vegetation frostbite (Mahrt and Larsen 1982; Hootman and Blumen 1983; Wang et al. 1995; Mahrt et al. 2001). The thermal internal boundary layer is formed over land with different diffusive characteristics below and above the layer, affecting the air quality along the coastal region (Gaza 1998; Luhar et al. 1998; Prabha et al. 2002; Miller et al. 2003; Salvador et al. 2016).

\footnotetext{
*Correspondence: ngeograph2@gmail.com; moonsoo@hufs.ac.kr Research Center for Atmospheric Environment, Hankuk University of Foreign Studies, 81 Oedae-ro, Mohyeon-myeon, Cheoin-gu, Yongin-si, Gyeonggi-do 17035, South Korea
}

Sea-land breezes or mountain-valley breezes sometimes interact with urban-rural breezes, complicating detailed local meteorological features (Bornstein and Tompson 1981; Freitas et al. 2007; Dandou et al. 2009; Ryu and Baik 2013; Ganbat et al. 2015; Hu and Xue 2016). It is well known that the inland penetration of sea breezes is retarded because of the increased surface roughness of cities (Thompson et al. 2007). Furthermore, the sea breeze is accelerated or decelerated depending on the urbanward convergent flow induced by the urban heat island.

Many observational features about the sea breezes have been broadly reported (Changnon et al. 1971; Oke 1978; Balling et al. 1990; Dixon and Mote 2003; Freitas et al. 2007). A sea-breeze front at the landward edge of circulation advances inland at a rate of $5-16 \mathrm{~km} \mathrm{~h}^{-1}$, accompanied by an increase in relative humidity, a decrease in temperature, and an abrupt change in wind direction and speed (Nakane and Sasano 1986; Yoshikado and Kondo 1989; Abb and Physick 1992; Miller et al. 2003). The 
sea-breeze penetration has a wide range, from $15 \mathrm{~km}$ in Alaska to $300 \mathrm{~km}$ in Australia at around 1500-1900 LST (Atkinson 1981; Kozo 1982; Simpson 1994; Tijm et al. 1999; Miller et al. 2003; Drobinski et al. 2006). The height of the sea-breeze head grows to $1300 \mathrm{~m}$ or so, and an overhead returning flow is often observed (Nakane and Sasano 1986; Banta 1995; Tijm et al. 1999). The detailed features of sea breeze are regarded as specific to the geographical location and conditions.

The Seoul Metropolitan Area (SMA), noted in 2015 as the world's fifth largest urban area in terms of population, has a very complex geography, topography, and land cover distribution (Demographia 2015; Park et al. 2017). Thus, local circulations are expected to be very complicated. There have been model-based studies on sea breezes in SMA (Jeong et al. 2008; Pokhrel and Lee 2011; Ryu and Baik 2013). However, maximum penetration distance of sea breeze has been reported with a variable range from $24 \mathrm{~km}$ (Jeong et al. 2008), $30 \mathrm{~km}$ (Pokhrel and Lee 2011), and $45 \mathrm{~km}$ (Ryu and Baik 2013). Although the penetration distance of sea breeze has been reported to have a wide range, there have been few observationbased studies in the SMA. Additionally, like in the case of sea breeze, there have been very few studies on the features of land breeze in the area.

Recently, an urban meteorological observation system in the SMA (UMS-Seoul) was installed by the weather information service engine (WISE) and Korea Meteorological Administration. It includes very high resolution surface meteorological stations and several surface-based remote sensing stations (Park et al. 2017). The former could provide information regarding high-resolution surface meteorological features, while the latter could collect data on the vertical structure of local circulation.

Therefore, this study investigates temporal, horizontal, and vertical features of the sea and the land breezes in the SMA by analyzing 6-day average detailed surface meteorological variables and time-height cross sections of wind using UMS-Seoul observed data for the period of 17-22 May 2016.

\section{Domain and instrumentation Domain}

Figure 1 shows the research domain and the location of the meteorological stations used in this study. The SMA consists of three administrative provinces: Seoul, Incheon, and Gyeonggi Province. The Yellow Sea is to the west of the SMA separated by a very irregular coastline. The western part of the SMA comprises relatively low-lying farmland and urban areas, whereas the eastern part contains high-altitude mountain ranges, some of which are higher than $1000 \mathrm{~m}$. Highly populated areas include Incheon, Seoul, and the southern Gyeonggi Province. Detailed descriptions of topography and land use can be found in Park et al. (2017).

\section{Sites and instrumentation}

Two types of meteorological observation stations are used: surface meteorological observation stations and wind lidar stations (Fig. 1). There are 381 integrated meteorological observation (IMO) stations operated by SKTechX, that are used for observation of the horizontal distribution of surface meteorology. Each IMO station has an IMO sensor and a precipitation gauge on the telecommunication tower. Each IMO sensor measures air temperature, relative humidity, wind speed, wind direction, and air pressure at the same altitude. Most IMO stations are installed over the rooftop of a building near populated urban areas. The station density is designed to be roughly proportional to the population density. For example, the stations have a dense horizontal resolution of $1.5 \times 1.5 \mathrm{~km}^{2}$ in Seoul, but a coarse resolution of $9.5 \times 9.5 \mathrm{~km}^{2}$ elsewhere. All surface meteorological data are averaged every minute. The quality check for these data is implemented using an algorithm developed by Chae et al. (2014). The air temperature is corrected with respect to the sea-level height of sensors considering the monthly mean temperature lapse rate $\left(4.8 \mathrm{~K} \mathrm{~km}^{-1}\right)$ of the free atmosphere observed by a rawinsonde at the Osan World Meteorological Organization (WMO) upper-air measurement station (Fig. 1; Park et al. 2014).

Seven stations are selected to analyze the diurnal variation of surface meteorological variables with respect to their distance from the shoreline. Station 1 is on an offshore island $\sim 10 \mathrm{~km}$ from the shoreline; whereas, the other stations are inland at variable distances from the shoreline. Among them, Stations 3, 4, and 5 are in western (23 km from shoreline), middle of $(36 \mathrm{~km})$, and eastern $(46 \mathrm{~km})$ Seoul, respectively. Meanwhile, Stations 6 and 7 are located in mountainous terrain, $56 \mathrm{~km}$ and $74 \mathrm{~km}$ from the shoreline, respectively.

Three wind lidars (Windcube-200, Leosphere) are installed at the Bucheon, Gwanghwamun, and Jungnang Stations, to the west, in the center, and to the east of Seoul, respectively (Fig. 1 ). They provide a vertical profile of wind speed and direction at 50-m intervals up to maximum $6 \mathrm{~km}$ (typically to the boundary-layer height) with a 10-min temporal resolution. The following quality check procedure is applied to remove noisy data: carrier-to-noise check, data availability check, and vertical gradient of horizontal wind check in addition to the basic missing data check (Park and Choi 2016). 


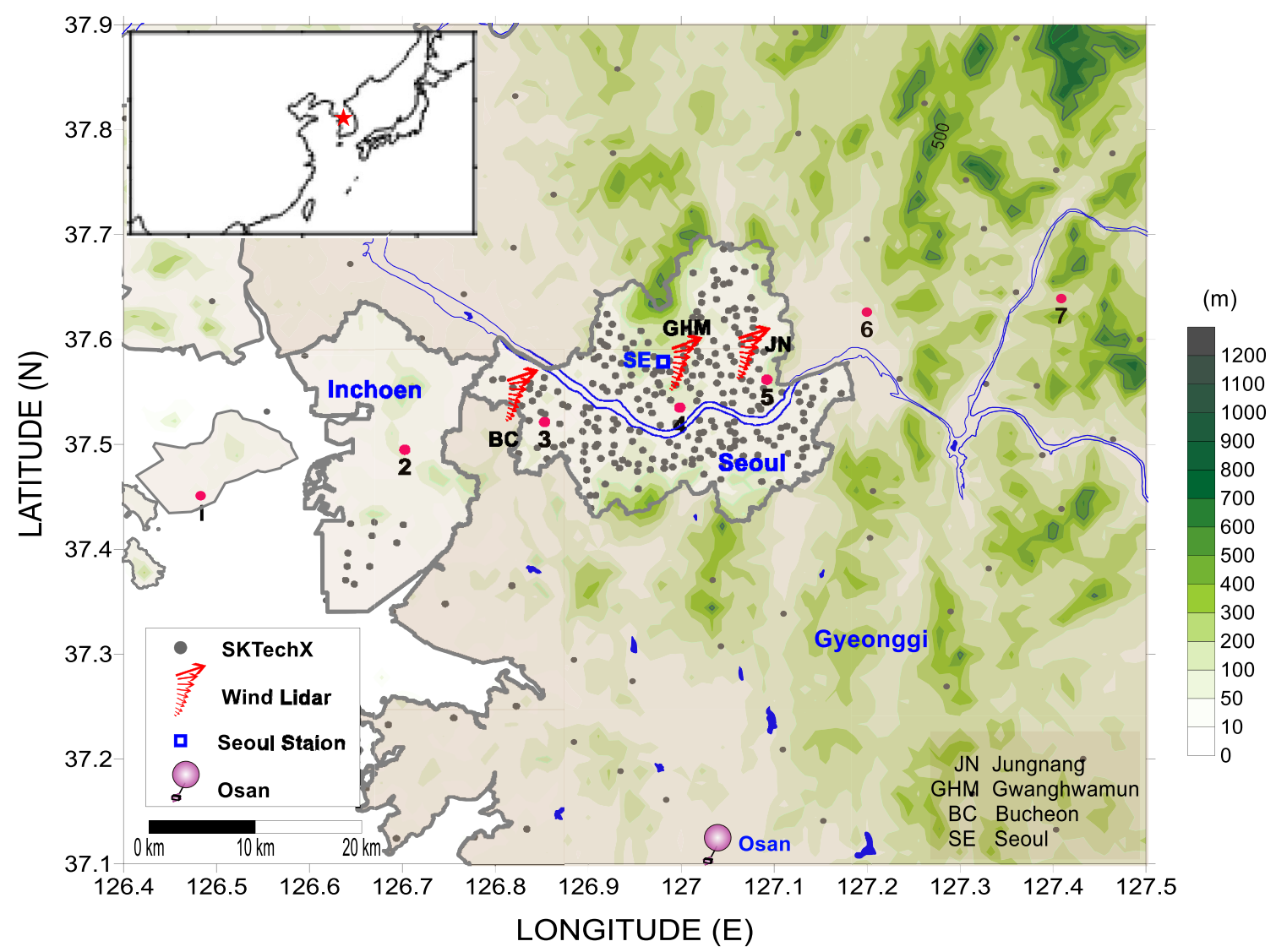

Fig. 1 Location of the SKTechX surface meteorological observation stations, wind lidar stations, Seoul automatic synoptic observation station, and Osan upper-air station in the Seoul Metropolitan Area. Selected SKTechX stations are indicated by the red-filled circle with the number

\section{Results and discussion Meteorology}

To find the overall local circulation features, the period from 17 to 22 May 2016, consecutively weak synoptic winds and less-cloudy conditions, was selected. Weather charts indicated that a zonal anticyclone in northern Japan blocked an eastward moving weather system. Thus, the synoptic weather system was stagnant throughout that period. Therefore, wind speeds of $850 \mathrm{hPa}$ at 0000 UTC (0900 LST), observed at the Osan WMO upperair measurement station (47122), were very weak, ranging from 2 to $5.5 \mathrm{~m} \mathrm{~s}^{-1}$. Daily mean wind speed at the Seoul station was recorded as $1.6-2.0 \mathrm{~m} \mathrm{~s}^{-1}$, lower than the monthly (May 2016) mean wind speed of $2.4 \mathrm{~m} \mathrm{~s}^{-1}$. Additionally, daily mean cloud cover was low, ranging between 0 and $28 \%$, which was much lower than the monthly mean cloud cover of $46 \%$ (http://www.weath er.go.kr).

Figure 2a shows the 6-day averaged diurnal variation of temperature, sea-level pressure, and wind vector at seven different stations (Fig. 1). The diurnal variation of temperature exhibited a typical diurnal pattern of both sea and land, with low amplitude on an offshore island (Station 1) and high amplitude in most inland areas (Stations 6 and 7) (Yamato et al. 2017). The offshore island (Station 1) exhibited the lowest daily maximum temperature in the daytime, but did not exhibit the highest minimum temperature in the nighttime. Instead, urban areas (Stations 3,4 , and 5) exhibited the highest minimum temperature at nighttime because of the urban heat island effect. The far-east and most inland areas (Stations 6 and 7) showed the lowest temperatures from 2000 LST to 0800 LST among the inland areas, partially due to the mountainous terrain. They showed slightly lower than or nearly the same temperature as the non-Seoul inland areas during the rest of the day. In the evening, the eastern (Station 5), central (Station 4), and western (Station 3) Seoul stations indicated the highest, the second highest, and the third highest temperatures, respectively. The higher temperature in Seoul's urban areas induced a significant urban-rural breeze.

Because temperature differences between the land and sea induce a pressure difference between the two, sealand breezes occur. The diurnal variation of sea-level 


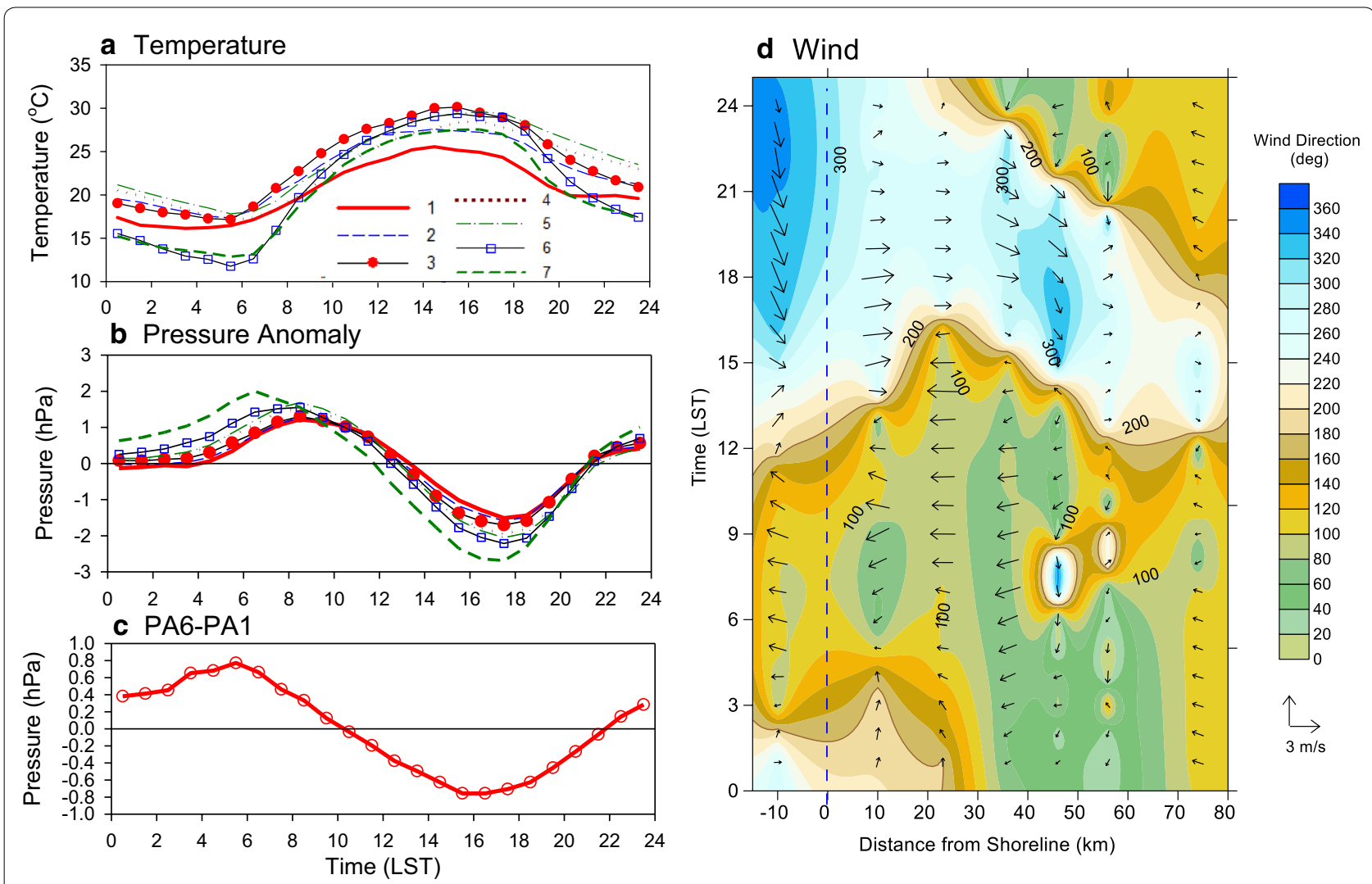

Fig. 2 Diurnal variation of a air temperature, $\mathbf{b}$ surface pressure anomaly at 7 stations, $\mathbf{c}$ pressure anomaly difference between Stations 6 and 1, and $\mathbf{d}$ time-distance cross section of wind at seven stations in the SMA. All data are averaged for the period of 17-22 May 2016, and the station number is indicated in Fig. 1

pressure anomalies (PAs) are depicted in Fig. 2b. The diurnal variation of sea-level PA at each station exhibited a semi-diurnal wave: the first peak was in the morning and the second was at midnight as documented in previous studies (Tijm et al. 1999; Dai and Wang 1999; Huang et al. 2010; Park 2018). The offshore island (Station 1) showed the lowest maximum sea-level PA and the highest minimum sea-level PA. The most inland area (Station 7) showed the largest maximum and lowest minimum pressures, and, subsequently, the maximum daily sealevel pressure range. Amplitude and phase of PA varied according to the distance from the shoreline. Except for the most inland area (Station 7), the difference between the inland and offshore PA remained positive from 2200 to 1000 LST, and negative from 1100 to 2100 LST (Fig. 2c). The positive (negative) difference produced the sea-to-land directional pressure gradient force, which is the main force driving the land (sea) breeze in this area (Simpson 1994; Tijm et al. 1999).

To determine the sea-breeze and land-breeze regime, the diurnal variations of wind at seven different stations are shown in Fig. 2d. It was found that wind direction and speed depended on the time of day and the distance from the shoreline. Easterly winds (land breeze) started at 1900 LST and continued until 1200 LST in the most inland area (Station 7); whereas, it started at midnight and continued until 1500 LST in the middle of Seoul (Station 4). Westerly winds (sea breeze) started at 1300 LST and ended at 0100 LST at an offshore island, whereas it started between 1600 and 1700 LST and ended between 2000 and 2300 LST in Seoul's urban areas. Weak westerly winds between 1300 and 1600 LST in the most inland area (Station 7) seemed not to be directly related to the sea breeze, owing to spatial inconsistencies. In summary, sea-breeze penetration started at an offshore island area at $1200 \mathrm{LST}$, moved landward at a rate of about $10 \mathrm{~km} \mathrm{~h}^{-1}$, and reached $60 \mathrm{~km}$ from the shoreline between 1700 and 1900 LST.

This result indicates that the penetration limit in this study was much larger than those reported by most previous studies: $10-25 \mathrm{~km}$ in Japan (Chiba et al. 1999), 20 (30) $\mathrm{km}$ with offshore (onshore) synoptic-scale winds (Simpson 1994), and $45 \mathrm{~km}$ from an urban canopy model in SMA (Ryu and Baik 2013). 


\section{Horizontal distributions of meteorological variables}

Figure 3 shows the horizontal distribution of the 6-day averaged hourly mean air temperature and sea-level air pressure at 6 -h intervals. The western (sea) regions exhibited a relatively high temperature, whereas the eastern (land) regions exhibited a relatively low temperature
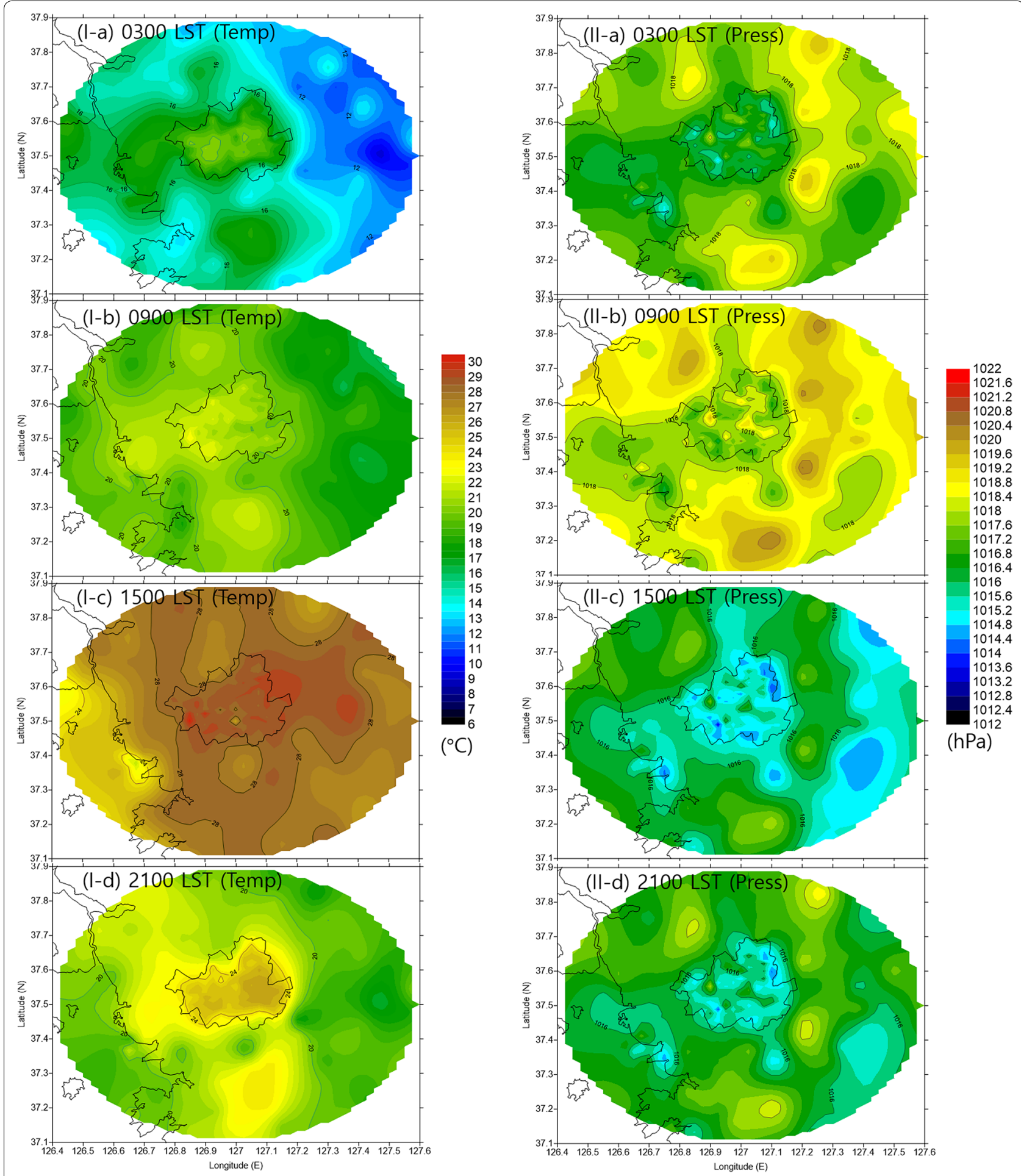

Fig. 3 Horizontal distribution of the air temperature (left) and sea-level pressure (right) at a 0300 LST, b 0900 LST, c 1500 LST, and d 2100 LST averaged over 6 days from 17 to 22 May 2016 
between 0000 and 0900 LST (Fig. 3Ia, b). Meanwhile, the eastern (land) regions exhibited a relatively high temperature, whereas the western (sea) regions exhibited a relatively low temperature between 1500 and 1800 LST (Fig. 3Ic).

The urban areas exhibited higher temperatures than the surrounding rural regions throughout the period, because of the urban heat island effect, resulting from the heat capacity difference between the urban and rural regions and anthropogenic heat release (Khan and Simpson 2001; Freitas et al. 2007; Ryu and Baik 2013). Temperature differences between eastern Seoul and neighboring rural areas were greater than $5{ }^{\circ} \mathrm{C}$ at $0300 \mathrm{LST}$ and were insignificant at $1500 \mathrm{LST}$ (Fig. 3Ia, c). These temperature differences can induce urban-rural circulation.

The hottest temperature in eastern Seoul and the lower temperature in western Seoul at 1800 LST could be the result of a temperature decrease after the passage of the sea-breeze front. The urban area in Seoul exhibited higher temperatures by $1-2{ }^{\circ} \mathrm{C}$ over Incheon and Gyeonggi province at nighttime (Fig. 3Ia, d), owing to building density. The horizontal distribution of air temperature was sufficient for the land-sea breeze as well as the urban-rural breeze. Moreover, sea-level pressure oppositely responded to air temperature, owing to its buoyancy (Fig. 3II). That is to say, the eastern part of Seoul (land direction) exhibited higher sea-level pressures than the western part of Seoul (sea direction) at nighttime, whereas the former exhibited lower pressure than the latter in daytime. The Seoul area exhibited lower sea-level pressures than the surrounding areas by about $1 \mathrm{hPa}$, mainly because of higher temperatures.

To discriminate the effect of different land cover conditions on the daily range of air temperature and pressure, the horizontal distribution of the 6-day averaged daily temperature and air pressure ranges during 17-22 May 2016 were investigated (Fig. 4). Daily temperature differences showed a low temperature difference $\left(<12{ }^{\circ} \mathrm{C}\right)$ in the western sea region and a high temperature difference $\left(>18^{\circ} \mathrm{C}\right.$ ) in eastern land region (Fig. 4a), owing to the difference in heat capacity between the two. Because of the higher temperature at nighttime in urban areas related to heat storage by buildings and roads, daily temperature differences in Seoul, especially western Seoul, were much smaller than those in the surrounding rural regions. Daily pressure differences ranged from $2.8 \mathrm{hPa}$ in the western (sea) region to above $4.0 \mathrm{hPa}$ in the eastern (land) region (Fig. 4b). The contours were roughly parallel with the shoreline. This implies that the effect of urban areas on the daily pressure difference was not as significant as that of the daily temperature differences.

To investigate the characteristics of surface meteorological variables when the sea-breeze front passes, an enhanced time series and a 1-min horizontal distribution were analyzed, respectively (Figs. 5 and 6). An abrupt temperature drop $\left(30.6-29.6{ }^{\circ} \mathrm{C}\right)$ and vapor pressure increase (5.9-11.2 hPa) were observed during 2-min span from 1718 to 1720 LST at Jungnang Station (Fig. 5), which was accompanied by a sea-breeze front passage. During this period, wind direction did not change significantly. However, wind speeds increased from 1.5 to $4 \mathrm{~m} \mathrm{~s}^{-1}$. Horizontal distributions of temperature and wind at 1700, 1730, and 1800 LST supported the seabreeze front passage (Fig. 6). An isotherm line between 28 and $30{ }^{\circ} \mathrm{C}$, with the very steep west-east horizontal gradient of temperature, was in the middle of Seoul at 1700 LST (Fig. 6a). It moved eastward (landward) at 1730 LST and passed by the Jungnang Station at 1800 LST on 20 May, 2016 (Fig. 6b, c). The propagation speed of the front was about $10 \mathrm{~km} \mathrm{~h}^{-1}$, which was the same as the speed shown in Fig. 2d. Landward areas of the $30{ }^{\circ} \mathrm{C}$ contour line exhibited low wind speeds and an irregular wind direction, whereas the seaward area of the $28{ }^{\circ} \mathrm{C}$ contour line exhibited strong westerly winds. It was also found that the contour line of $28{ }^{\circ} \mathrm{C}$ was retarded in the middle of Seoul at 1700 LST (Fig. 6a), which could be evidence of sea-breeze penetration retardation in urban areas, caused by increased surface roughness from highrise buildings (Thompson et al. 2007).

\section{Vertical profile of wind}

To investigate the vertical structure of the sea-land breeze, the 6-day averaged vertical profiles of wind observed by a pulsed Doppler wind lidar at Bucheon, Gwnaghwamun, and Jungnang Stations were drawn (Fig. 7). Time-height cross sections of wind gave not only temporal, but also vertical regimes of sea and land-breeze circulations for each station.

The sea breeze started at 1500 LST, 1600 LST, and 1700 LST and ended at 2200 LST, 2100 LST, and 2000 LST at Bucheon, Gwanghwamun, and Jungnang Stations, respectively. Thus, the duration of the sea breeze decreased with distance from the shoreline. There were two sea-breeze cells during the 1500-1800 LST and 1900-2200 LST at Bucheon Station, and one cell at the other stations. The top of the sea breeze reached a maximum height of 1.1-1.5 $\mathrm{km} 1 \mathrm{~h}$ after the sea-breeze front passage. Then, it decreased slowly. The maximum height of the sea-breeze head was nearly the same as those suggested in previous studies (Nakane and Sasano 1986). In the sea-breeze cells, maximum winds occurred from near the surface to $0.4 \mathrm{~km}$ from 1600 to 1900 LST with the strongest wind at the Gwanghwamun Station. The returning (easterly) flow was clearly observed over the sea-breeze cells of 1.5-1.6 km height at the Gwanghwamun and Jungnang Stations. 

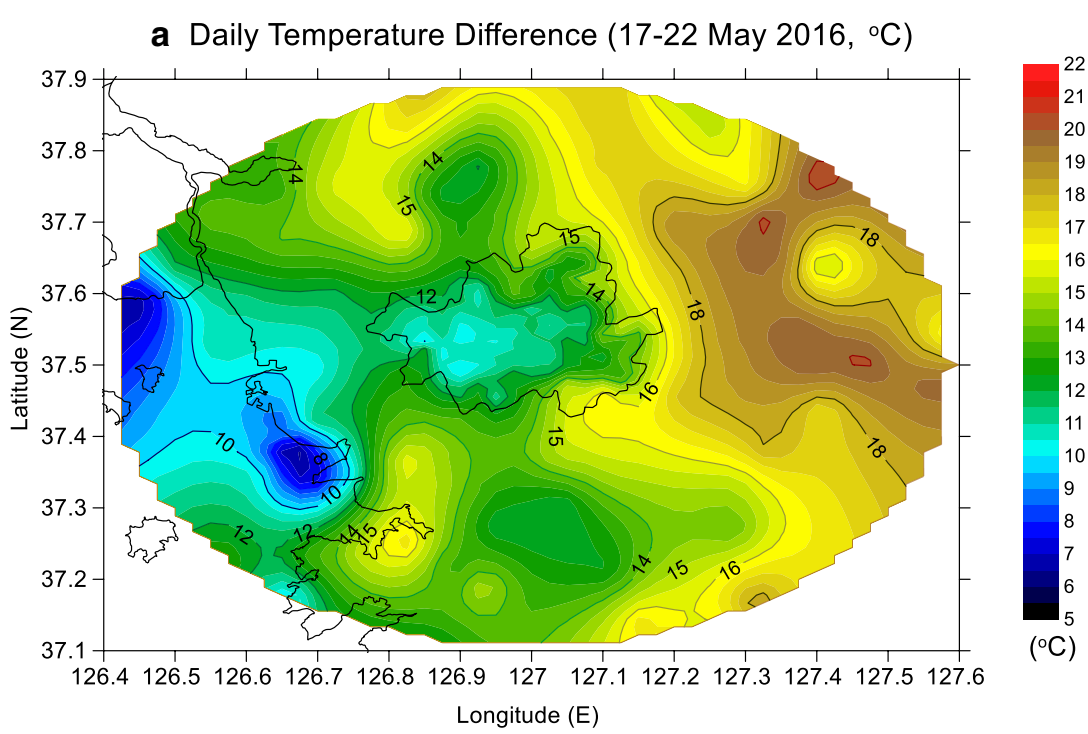

b Daily Pressure Difference (17-22 May 2016, hPa)

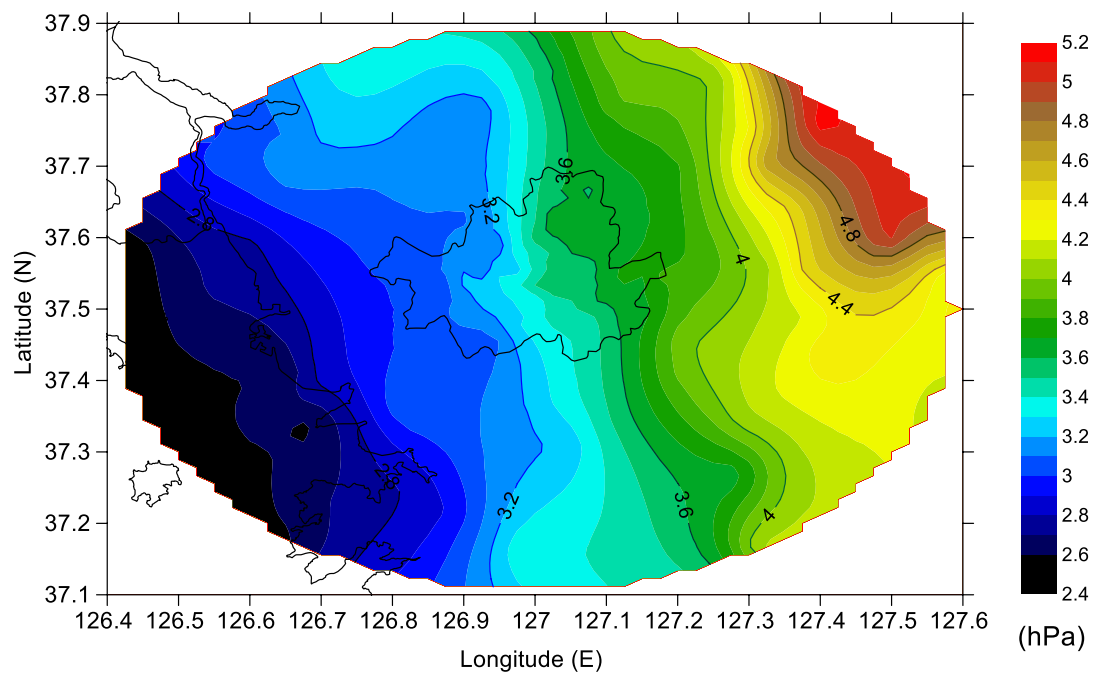

Fig. 4 Horizontal distribution of period mean daily differences of a air temperature and $\mathbf{b}$ pressure averaged over 6 days from 17 to 22 May 2016

The surface land breeze started at 0100 LST, 2300 LST, and 2300 LST, and ended at 1100 LST, 1100 LST, 1200 LST at Bucheon, Gwnaghwamun, and Jungnang Stations, respectively. The land-breeze cell evolved from 0.2 to $0.4 \mathrm{~km}$ between 0200 and $0300 \mathrm{LST}$, and reached $0.7-0.8 \mathrm{~km}$ between 0900 and 1000 LST. In the land-breeze cells, maximum easterly winds occurred at 0.3-0.4 km heights between 0600 and 0700 LST, corresponding to the large difference in PA between the land and sea (Fig. 2c). Above the land-breeze cells, northerly strong winds blew with its core at 1.4-1.6 km heights between 0600 and 0800 LST.

During the land-sea intermediate period, weak southerly winds were observed at the Gwanghwamun and
Jungnang Stations. This may be related to other local circulations (e.g., mountain-valley breezes).

\section{Summary}

The detailed surface meteorological and vertical profile features of the sea-land-breeze circulation were investigated using UMS-Seoul data obtained from high-resolution surface meteorological observation stations and three wind lidar stations. The experimental period lasted from 17 to 22 May 2016, having very weak synoptic winds and low cloud covers.

The 6-day averaged diurnal variation of surface meteorological variables at seven different stations chosen with respect to their distance from the shoreline 


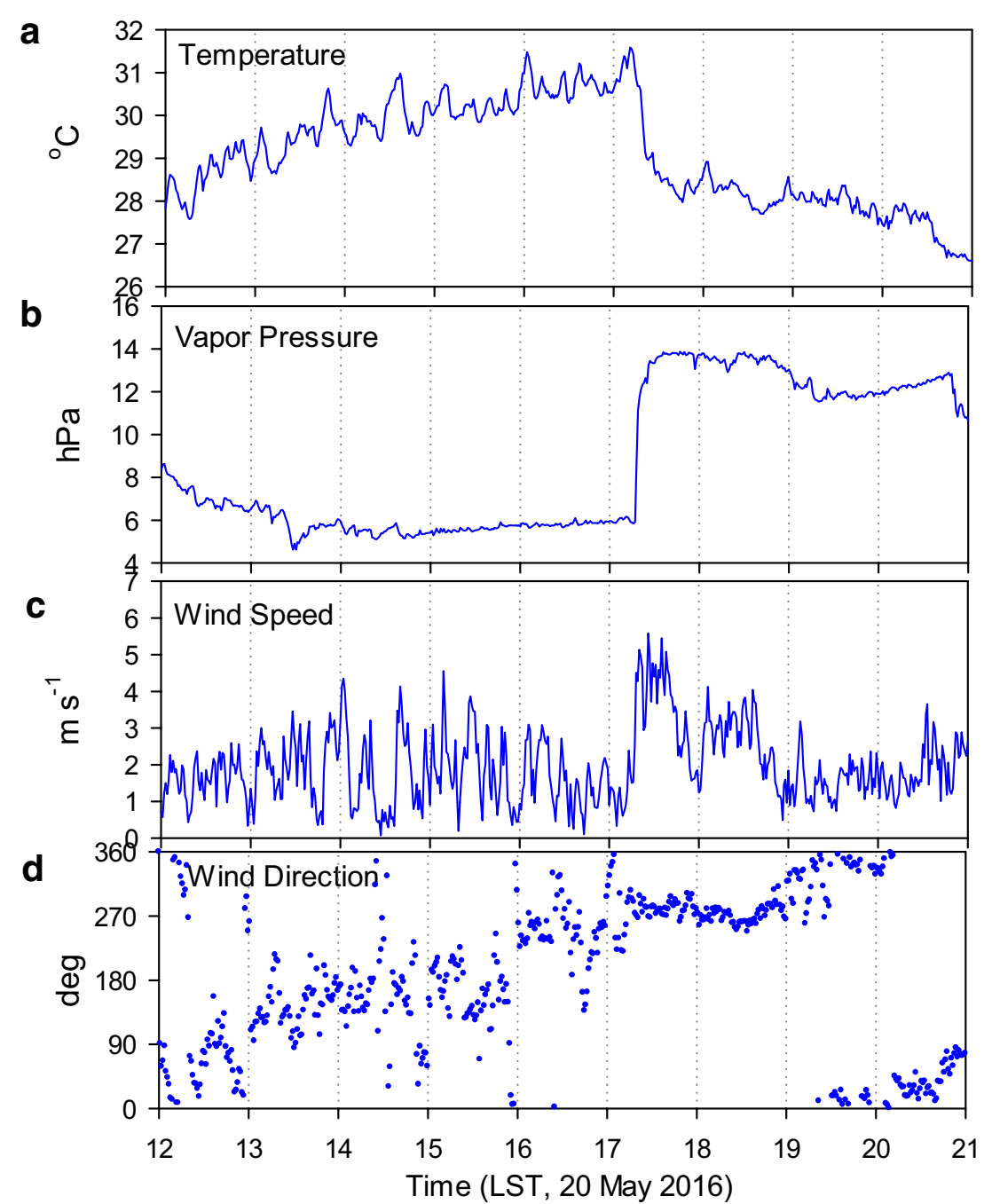

Fig. 5 Time series of a air temperature, $\mathbf{b}$ vapor pressure, $\mathbf{c}$ wind speed, and $\mathbf{d}$ wind direction at the Jungnang Station between 1200 and 2100 LST on 20 May 2016

indicated that the temperature differences between the land and sea could induce the pressure difference between the two. Amplitude difference and phase shift of the sea-level PA with respect to the distance from the shoreline produced the pressure differences between the sea and land. These were the major forces driving the sea-land circulation. Therefore, diurnal variations of wind indicated that the starting and ending times of surface land and sea breezes were determined by the distance from the shoreline. The sea-breeze front began at the shoreline at 1200 LST, moved landward at a rate of about $10 \mathrm{~km} \mathrm{~h}^{-1}$, and reached $60 \mathrm{~km}$ inland at $1800 \mathrm{LST}$. The land breeze occurred at areas within $50 \mathrm{~km}$ of the shoreline with a maximum in the early morning.

The horizontal distributions of temperature and pressure exhibited distinct temperature and pressure differences not only between land and sea regions, but also between urban and rural regions, respectively. They made possible not only sea-land breezes, but also urban-rural breezes. The hottest temperature in eastern Seoul in the late afternoon resulted from the temperature drop behind the sea-breeze front. The urban areas in Seoul exhibited the highest temperature by 

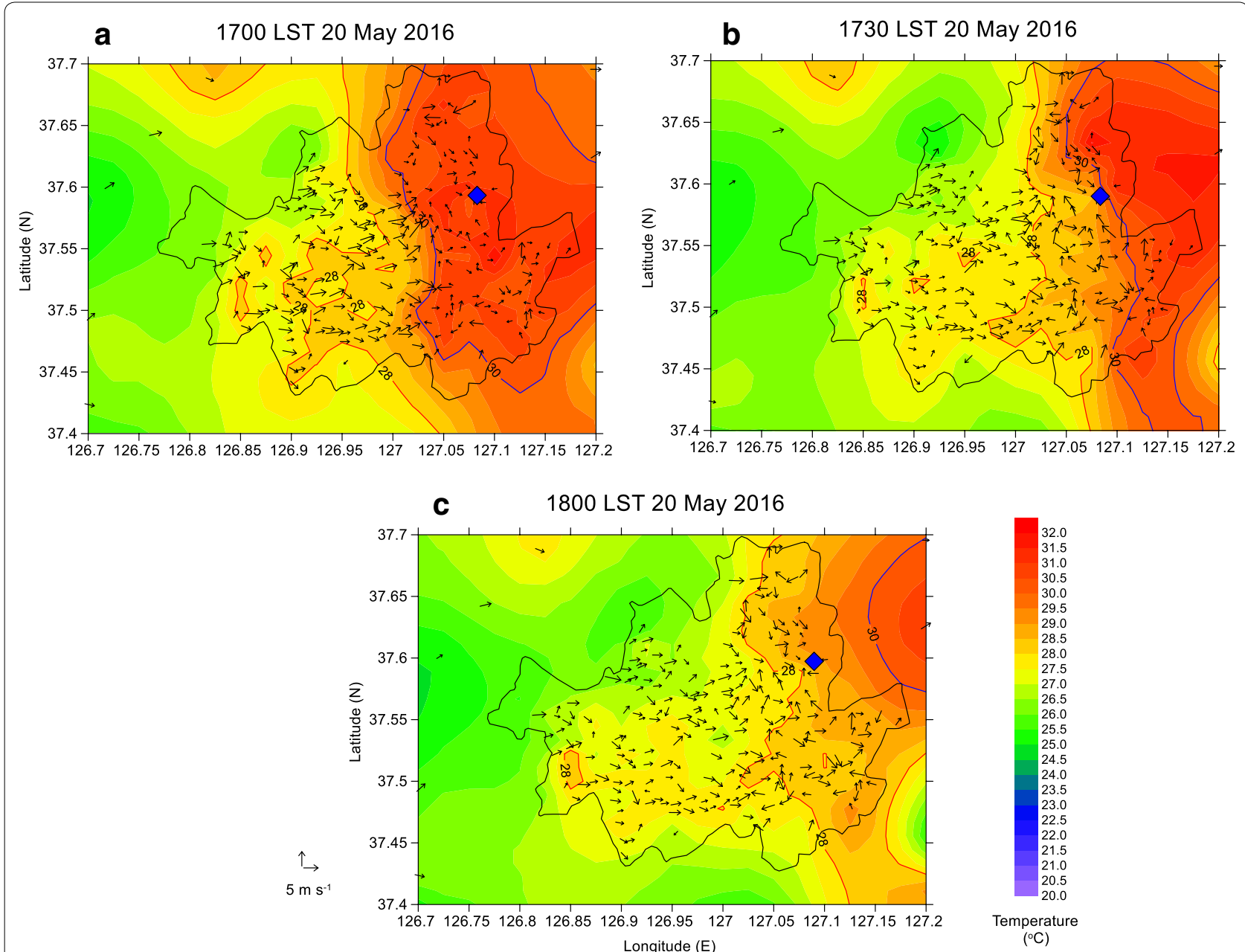

Fig. 6 Horizontal distribution of air temperature (contour) with wind (arrow) at a 1700 LST, b 1730 LST, and c 1800 LST. The Jungnang Station is indicated by the blue-filled diamond

$1-2{ }^{\circ} \mathrm{C}$ over the urban areas at Incheon and Gyeonggi Province at nighttime, owing to denser and higher buildings. Daily temperatures and pressure ranges exhibited distinct differences between the land (large difference) and the sea (small difference). Daily temperature differences in Seoul, especially western Seoul, were much smaller than those in the surrounding rural regions because of higher temperatures at nighttime.

Through an enhanced time series and horizontal distribution of meteorological variables, abrupt temperature drop, vapor pressure, and wind-speed increases occurred when a sea-breeze front passed. Isothermal lines with very steep temperature gradients demarked the sea-breeze front, which was sometimes retarded owing to urban high-rise buildings.

Through time-height cross-section wind analysis, the temporal and vertical regimes of sea- and land-breeze circulation could be checked. Time-height cross section of wind gave temporal and vertical regimes of the sea- and land-breeze circulations for each station. The top-of-sea (land) breeze reached a maximum height of $1.5 \mathrm{~km}(0.8 \mathrm{~km})$ with maximum winds of $0.4 \mathrm{~km}(0.3-$ $0.4 \mathrm{~km}$ ) in the late afternoon (in the early morning). The returning (easterly) flow was clearly observed over the sea-breeze cells of $1.5-1.6 \mathrm{~km}$ height. 

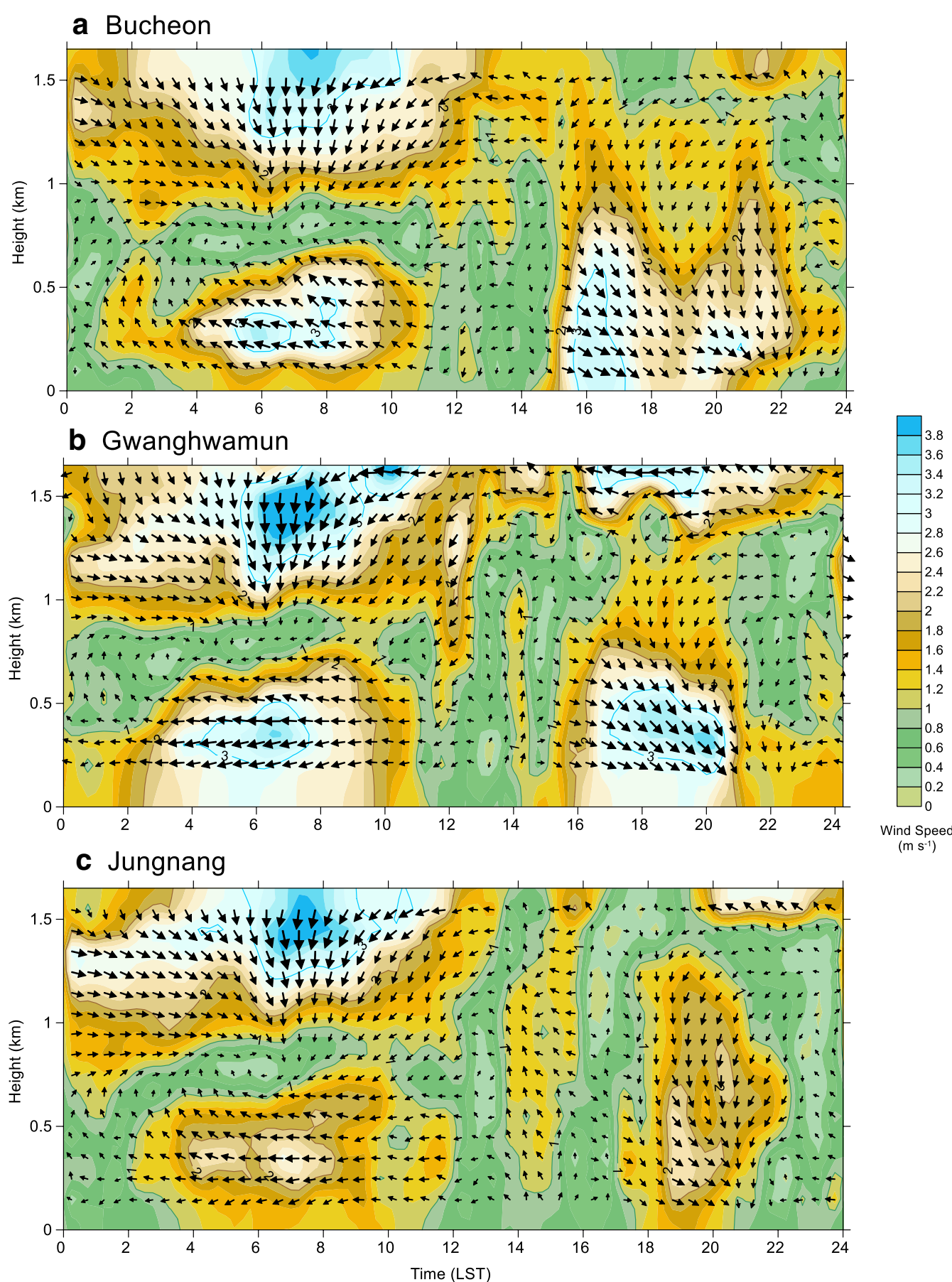

Fig. 7 Time-height cross sections of wind speed (contour, arrow size) and direction (arrow) obtained by wind lidar averaged over 6 consecutive days from 17 to 22 May 2016 at a Bucheon, b Gwanghwamun, and c Jungnang Stations

Because the observed wind is a sum of synoptic, sealand breeze, urban-rural breeze, and other minor local breeze components, it is still very difficult to extract only one component of local wind.

\section{Abbreviations}

IMS: integrated meteorological observation; LST: local standard time (+09 UTC); PA: pressure anomaly; SKTechX: a subsidiary company of a telecommunication company, SK, in Korea; SMA: Seoul Metropolitan Area; UMS-Seoul: urban meteorological observation system in the SEOUL Metropolitan Area; WISE: weather information service engine. 


\section{Authors' contributions}

M-SP designed, and coordinated all researches, and analyzed the wind lidar data. J-HC monitored and analyzed the SKTechX data. Both authors read and approved the final manuscript.

\section{Acknowledgements}

This work was funded by the Korea Meteorological Administration Research and Development Program under Grant KMI2018-05310. All data used in this study were jointly provided by the Korea Meteorological Administration (Weather Information Service Engine Project) and Hankuk University of Foreign Studies.

\section{Competing interests}

The authors declare that they have no competing interests.

\section{Availability of data and materials}

Data used in this study can be provided upon request. For further inquiries, please contact either Dr. Moon-Soo Park (ngeograph2@gmail.com) or Mr. Jung-Hoon Chae (zhzhah79@gmail.com) by e-mail.

\section{Consent for publication}

This is original work that has not been submitted for any other publication.

\section{Ethics approval and consent to participate}

Not applicable.

\section{Funding}

This work was funded by the Korea Meteorological Administration Research and Development Program under Grant KMI2018-05310.

\section{Publisher's Note}

Springer Nature remains neutral with regard to jurisdictional claims in published maps and institutional affiliations.

Received: 24 March 2018 Accepted: 12 November 2018 Published online: 19 November 2018

\section{References}

Abb DJ, Physick WL (1992) Sea-breeze observations and modelling: a review. Aust Meteorol Mag 41:7-19

Atkinson BW (1981) Mesoscale atmospheric circulations. Academic Press 495:pp

Balling RC, Skindlov JA, Philips DH (1990) The impact of increasing summer mean temperatures on extreme maximum and minimum temperatures in Phoenix, Arizona. J Climate 3:1491-1494. https://doi. org/10.1175/1520-0442(1990)003\%3c1491;TIOSM\%3e2.0.CO;2

Banta RM (1995) Sea breezes shallow, and deep on the California coast. Mon Weather Rev 123:3614-3622. https://doi.org/10.1175/15200493(1995)123\%3c3614:SBSADO\%3e2.0.CO;2

Bornstein RD, Tompson WT (1981) Effects of frictionally retarded sea breeze and synoptic frontal passages on sulfur dioxide concentration in New York City. J Appl Meteorol 20:843-858. https://doi.org/10.1175/15200450(1981)020\%3c0843;EOFRSB\%3e2.0.CO;2

Chae J-H, Park M-S, Choi YJ (2014) The WISE quality control system for integrated meteorological sensor data. Atmos Korea Meteorol Soc 24(3):445-456. https://doi.org/10.1419/Atmos.2014.24.3.445

Changnon SA, Huff FA, Semonin RG (1971) METROMEX: an investigation of inadvertent weather modification. Bull Am Meteorol Soc 52:958-968

Chiba O, Kobayashi F, Naito G, Sassa K (1999) Helicopter observations of the sea breeze over a coastal area. J Appl Meteorol 38:481-492

Dai A, Wang J (1999) Diurnal and semidiurnal tides in global surface pressure fields. J Atmos Sci 56:3874-3891. https://doi.org/10.1175/15200469(1999)056\%3c3874:DASTIG\%3e2.0.CO;2

Dandou A, Tombrou M, Soulakellis N (2009) The influence of the city of Athens on the evolution of the sea-breeze front. Bound-Layer Meteorol 131:35-51. https://doi.org/10.1007/s10546-008-9306-x
Demographia (2015) Demographia world urban areas, built up urban areas or world agglomeration, 11th edn. Demographia, Illinois, p 133

Dixon PG, Mote T (2003) Patterns and causes of Atlanta's urban heat island -initiated precipitation. J Appl Meteorol 42(9):1273-1284. https //doi.org/10.1175/1520-0450(2003)042\%3c1273;PACOAU\%3e2.0.CO;2

Drobinski P, Bastin S, Dabas A, Delville P, Reitebuch O (2006) Variability of three-dimensional sea breeze structure in southern France: observations and evaluation of empirical scaling laws. Ann Geophys 24:1783-1799. https://doi.org/10.5194/angeo-24-1783-2006

Freitas E, Rozoff CM, Cotton WR, Dias PLS (2007) Interactions of an urban heat island and sea-breeze circulations during winter over the metropolitan area of Sao Paulo, Brazil. Bound-Layer Meteorol 122:43-65. https://doi.org/10.1007/s10546-006-9091-3

Ganbat G, Baik J-J, Ryu Y-H (2015) A numerical study of the interactions of urban breeze circulation with mountain slope winds. Theor Appl Climatol 120:123-135. https://doi.org/10.1007/s00704-014-1162-7

Gaza RS (1998) Mesoscale meteorology and high ozone in the northeast United States. J Appl Meteorol 37:961-977

Hootman BW, Blumen W (1983) Analysis of nighttime drainage winds in Boulder, Colorado during 1980. Mon Weather Rev 111:1052-1061. https://doi.org/10.1075/1520-0493(1983)111\%3c1052;AONDW $1 \% 3 e 2.0 .60: 2$

Hu X-M, Xue X (2016) Influence of synoptic sea-breeze fronts on the urban heat island intensity in Dallas-Fort Worth, Texas. Mon Weather Rev 144(4):1487-1507. https://doi.org/10.1175/MWR-D-15-0201.1

Huang W-R, Chan JCL, Wang S-Y (2010) A planetary-scale land-sea breeze circulation in East Asia and the western North Pacific. Q J R Meteorol Soc 136:1543-1553. https://doi.org/10.1002/qj.663

Jeong J, Lee IH, Lee H (2008) Estimation of the effective region of sea/land breeze in west coast using numerical modeling. J Korea Soc Atmos Enviorn 24(2):259-270. https://doi.org/10.5572/KOSAE.2008.24.2.259

Khan SM, Simpson RW (2001) Effect of a heat island on the meteorology of a complex urban airshed. Bound-Layer Meteorol 100:487-506. https:// doi.org/10.1023/A:1019284332306

Kozo TL (1982) An observational study of sea breezes along the Alaskan Beaufort sea coast: part I. J Appl Meteorol 21:891-905

Luhar AK, Sawford BL, Hacker JM, Rayner KN (1998) The Kwinana coastal fumigation study: I-growth of the thermal internal boundary layer. Bound-Layer Meteorol 89(3):385-405. https://doi.org/10.1023/A:10017 46303967

Mahrt L, Larsen S (1982) Small scale drainage front. Tellus 34:579-587. https //doi.org/10.1111/j.2153-3490.1982.tb01846.x

Mahrt L, Vickers D, Nakamur RA, Soler MR, Sun J, Burns S, Lenschow DH (2001) Shallow drainage flows. Bound-Layer Meteorol 101:243-260. https://doi.org/10.1023/A:1019273314378

Miller STK, Keim BD, Talbot RW, Mao H (2003) Sea breeze: structure, forecasting, and impacts. Rev Geophys 41(3):1011. https://doi. org/10.1029/2003RG000124

Nakane H, Sasano Y (1986) Structure of a sea-breeze front revealed by scanning lidar observation. J Meteorol Soc Jpn 64(5):787-792. https://doi. org/10.2151/jmsj1965.64.5 787

Oke TR (1978) Boundary layer climates. Rutledge, London, p 435

Park M-S (2018) Overview of meteorological surface variables and boundary-layer structures in the Seoul Metropolitan Area during the MAPS-Seoul campaign. Aerosol Air Qual Res 18:2157-2172. https://doi. org/10.4209/aaqr.2017.10.0428

Park M-S, Choi M-H (2016) Development of a quality check algorithm for the WISE pulsed Doppler wind lidar. Atmos Korea Meteorol Soc 26(3):461471. https://doi.org/10.14191/Atmos.2016.26.3.461

Park M-S, Joo SJ, Park S-U (2014) Carbon dioxide concentration and flux in an urban residential area in Seoul, Korea. Adv Atmos Sci 31:1101-1112. https://doi.org/10.1007/s00376-013-3168-y

Park M-S, Park S-H, Chae J-H, Choi M-H, Song Y, Kang M, Roh J-W (2017) High-resolution urban observation network for user-specific meteorological information service in the Seoul Metropolitan Area, South Korea. Atmos Meas Tech 10:1575-1594. https://doi.org/10.5194/ amt-10-1575-2017

Pokhrel R, Lee H (2011) Estimation of the effective zone of sea/land breeze in a coastal area. Atmos Poll Res 2(1):106-115. https://doi.org/10.5094/ APR.2011.013 
Prabha TV, Venkatesan R, Mursch-Radlagruber E, Rengarajan G, Jayanthi N (2002) Thermal internal boundary layer characteristics at a tropical coastal site as observed by a mini-SODAR under varying synoptic conditions. J Earth Syst Sci 111(1):63-77. https://doi.org/10.1007/BF027 02223

Ryu Y-H, Baik J-J (2013) Daytime local circulations and their interactions in the Seoul Metropolitan Area. J Appl Meteorol Climatol 52:784-801. https://doi.org/10.1175/JAMC-D-12-0157.1

Salvador N, Loriato AG, Santiago A, Albuquerque TTA, Reis NC Jr, Santos JM, Landulfo E, Moreira G, Lopes F, Held G, Moreira DM (2016) Study of the thermal internal boundary layer in sea breeze conditions using different parameterizations: application of the WRF model in the Greater Vitoria Region. Rev Bras Meteorol 31(4):593-609. https://doi. org/10.1590/0102-7786312314b20150093

Simpson JE (1987) Gravity currents: in the environment and the laboratory Wiley, New York, p 244

Simpson JE (1994) Sea breeze and local winds, vol 234. Cambridge University Press, Cambridge, p 234
Thompson WT, Holt T, Pullen J (2007) Investigation of a sea breeze front in an urban environment. Q J R Meteorol Soc 133:579-594. https://doi. org/10.1002/qj.52

Tijm ABC, Van Delden AJ, Holtslag AAM (1999) The inland penetration of sea breezes. Contrib Atmos Phys 72(4):317-328

Wang Q, Zhu P, Wang B, Jiang R (1995) Analysis of nighttime drainage wind in the HEIFE region. J Meteorol Soc Jpn 73(6):1285-1291. https://doi. org/10.2151/jmsj1965.73.6_1285

Yamato H, Mikami T, Takahashi H (2017) Impact of sea breeze penetration over urban areas on midsummer temperature distributions in the Tokyo Metropolitan area. Int J Climatol 37:5154-5169. https://doi.org/10.1002/ joc.5152

Yoshikado H, Kondo H (1989) Inland penetration of the sea breeze over the suburban area of Tokyo. Bound-Layer Meteorol 48:389-407

\section{Submit your manuscript to a SpringerOpen ${ }^{\odot}$ journal and benefit from:}

- Convenient online submission

- Rigorous peer review

- Open access: articles freely available online

- High visibility within the field

- Retaining the copyright to your article

Submit your next manuscript at $\gg$ springeropen.com 